\title{
Influence of Weather Factors on the Occurrence, Population Fluctuation and Species Diversity of Fruit Flies in Snake Gourd Ecosystem
}

\author{
L. Sowmiya ${ }^{1 *}$, M. Chandrasekaran ${ }^{2}$, R.P. Soundararajan ${ }^{2}$ and D. Ramesh ${ }^{2}$ \\ ${ }^{1}$ Anbil Dharmalingam Agricultural College and Research Institute \\ ${ }^{2}$ Horticultural College and Research Institute for Women, Tamil Nadu Agricultural University \\ Tiruchirappalli 620 027, Tamil Nadu, India \\ *Corresponding author
}

\section{A B S T R A C T}

\section{Keywords}

Snake gourd, Fruit fly, Occurrence, Species diversity, Cue lure, Methyl eugenol

\section{Article Info}

Accepted:

04 August 2020

Available Online:

10 September 2020
Snake gourd, Trichosanthes anguina L., in the family of cucurbitaceae is the most important tropical and sub-tropical vegetable, which contains lots of medicinal properties that cure people from blood pressure, heart disease, rheumatism and psoriasis. Fruit flies (Tephritidae: Diptera) are polphagous pest and widely distributed in subtropical, tropical and temperate regions of the world. Melon fruit fly, Zeugodacus cucurbitae Coquillett is the serious pest of all cucurbitaceous vegetable and reduces the yield of a crop. Adult flies create oviposition punctures on the fruit rind and hatched maggots from the eggs feed on the pulp portion of the fruit. The maggot feeding leads to reduce the marketability and unfit for human consumption. The intensity of the infestation of fruit fly is closely related with the weather parameters and species diversity in the particular location. To overcome the yield losses, there is a need for monitoring of pest species in relation with meteorological factors which helps to determine the management practices. To assess the seasonal occurrence, fluctuation and its species diversity the field experiment was conducted at farmer's field at Kumaravadi village, Tiruchirappalli during kharif and rabi season 2019-20. The fruit fly species of Z. cucurbitae, Z. gavisus and B. vishnu were trapped in cue lure baited traps and the species viz., B. dorsalis, B. zonata and B. correcta species were trapped in methyl eugenol traps and the species were taxonomically categorized. The maximum population was noticed and trapped in $35^{\text {th }}$ Standard Meteorological Week (SMW) i.e., 25.80 fruit flies/trap in kharif and $10^{\text {th }}$ SMW (12.3 fruit flies/trap) in rabi. On comparing the weather parameters relative humidity and rainfall shows negative correlation and other factors are positively correlated with the trap catches in both the seasons.

\section{Introduction}

Cucurbits are the most important summer vegetables in the family cucurbitaceae and grown throughout the year except winter season. In India, vegetable crops are cultivated in an area of 10100 ha with the productivity of 185883 MT (Anonymous, 2019). Snake gourd (Trichosanthes anguina $\mathrm{L}, 2 \mathrm{n}=22$ ) is an annual climber originated 
from India. It is also known as serpent gourd, viper gourd, club gourd, snake squash, chichinda, padwal and pudalangai in the southern states of India (Deepa Devi, 2017). The fruit contains essential nutrients like vitamin C (30.5\%), manganese (12.5\%), vitamin B6 (11.3\%), vitamin A (9.8\%), magnesium $(6.7 \%)$, iron $(5.7 \%)$ and calcium $(6.7 \%)$ for human diet. It acts as a traditional medicine and eliminates the toxins from the body by stimulate the liver and increases urination in human body (Mathew et al., 2019). In Tamil Nadu, snake gourd is cultivated in a total area of 1439 ha with a production of 35,411 tonnes and productivity of $17.66 \mathrm{t} / \mathrm{ha}$. The crop is mainly attacked by melon fruit fly, Zeugodacus cucurbitae Coquillett and causes varied yield losses from 30 to $60 \%$ depends on the season and cucurbit species/varieties (Dhillon et al., 2005). Adult female prefers to lay eggs inside the pulp portion of the fruit up to 2 to $4 \mathrm{~mm}$ deep by making ovipositional punctures on the fruit rind and the eggs emerged as maggots. Apart from fruit, they also lay eggs in corolla and stem region of a plant and also feed flowers (Narayanan, 1953). Infested fruit starts to decay by the action of saprophytic organisms like bacteria and fungi turns to rotten, deformed, and unfit for human consumption (Nasiruddin et al., 2004). Use of insecticides for the control of fruit fly is detrimental to consumers and environment also increases the cost of production, there is a need for alternative method that could be ecofriendly and effective (Neupane, 2000). Pheromone technology is viable option for the management as well as monitoring of fruit flies. Cue-lure (4-( $p$-acetoxyphenyl)-2butanone) and Methyl eugenol (4-allyl-1,2dimethoxy benzene carboxylate) were the highly attractive kairomone compound for Zeugodacus cucurbitae and Bactrocera dorsalis, respectively (Hardy, 1979). Field sanitation along with use of traps is the best alternative method of low cost, environmentally safe and high specificity for fruit fly management (Sureshbabu and Viraktamath, 2003). The fruit fly damage is varied depends upon the favourable climatic factors and wide diversity of host plants in the particular region. Therefore, it compels the understanding of its behavior with its existing environmental system. Keeping this in view, the present investigation was made to explore the occurrence, fluctuation and its diversity in snake gourd ecosystem.

\section{Materials and Methods}

The field experiment on the assessment of seasonal occurrence and diversity of fruit flies in relation to abiotic factors in snake gourd ecosystem was carried out during 2019-20, in the farmer's field of Kumaravadi village, Vaiyampatti block of Trichirappalli District located between $10^{0} 32^{\prime} \mathrm{N}$ latitude and $78^{0} 18^{\prime} \mathrm{E}$ longitude at an altitude of $219 \mathrm{~m}$ above the sea level.

The experiment was conducted by following standard meteorological weeks and the periodical observations were taken at weekly interval. The trap catches were properly preserved and subjected to taxonomical identification and categorization.

The parapheromone attractants viz., cue lure [4, (p-acetoxyphenyl)-2-butanone)] and methyl eugenol (4-allyl-1, 2-dimethoxy benzene carboxylate) were used for monitoring and trapping of fruit flies. A simple bottle trap device with lost cost material was used in the experiment for regular monitoring on the incidence and diversity of fruit flies in the field. Cylindrical disposed plastic water bottle having $10 \mathrm{~cm}$ diameter and $25 \mathrm{~cm}$ height with a screw lid was used as a trapping material. The bottles were cut open in a three square $(1.5 \mathrm{~cm} \times 1.5$ $\mathrm{cm})$ shaped entry slits with evenly spaced 10 $\mathrm{cm}$ below from the lid with the help of folding 
knife. A small hole was made in the centre portion of the lid for the use of hanging of cotton wick. A cotton thread was tied above the lid and half portion was inserted inside the bottle.

The attractant lures were prepared by mixing the commercially available laboratory grade cue lure or methyl eugenol, ethanol along with insecticide malathion $50 \mathrm{EC}$ at the ratio of $6: 4: 2$. A cotton wick $(2.5 \times 1 \mathrm{~cm})$ was saturated in the lure for $24 \mathrm{~h}$ and hung inside the bottle trap near the entry hole. Bottle trap was placed in the snake gourd ecosystem at $1.5 \mathrm{~m}$ height for monitoring and trapping of fruit flies. The traps were monitored at weekly interval and trapped fruit flies were collected for identification using the taxonomical keys of David and Ramani (2011). The cotton wicks were replaced at weekly intervals for continuous monitoring to record the data on seasonal incidence of different species of fruit flies in snake gourd.

The meteorological parameters viz., maximum temperature, minimum temperature, relative humidity and rainfall during the experimental period were collected from NASA ARC POWER website. The weather parameters were summarized into weekly averages and correlated with trapped adults of fruit flies to assess its season oriented changes in its population dynamics.

\section{Results and Discussion}

There was a significant and clear variation on the fruit fly species trapped in two different lures. In cue lure traps, the species viz. Zeugodacus cucurbitae (Coquillett), Zeugodacus gavisus (Munro) and Bactrocera vishnu (Drew and Handcock) were recorded. In methyl eugenol traps, Bactrocera dorsalis (Hendel), Bactrocera zonata (Saunders) and Bactrocera correcta (Bezzi) were identified from the collected trapped specimens.

\section{Fruit fly incidence during kharif 2019}

In kharif season, maximum of Zeugodacus cucurbitae species was recorded on $45^{\text {th }}$ Standard Meteorological Week (SMW) i.e., 9.7 fruit flies/ trap followed by $44^{\text {th }}$ SMW (9.6 fruit flies/trap) and the minimum trapping was recorded on $48^{\text {th }}$ SMW (3.6 fruit flies/trap) (Table 1). The data was significantly coincides with the finding of Raghuvashini et al., (2012), who reported peak activity of melon fruit fly occurs during 43 SMW (115/trap) in Agricultural research farm, Varanasi during 2003-2004. Zeugodacus gavisus species was more on $35^{\text {th }}$ SMW and minimum on $48^{\text {th }}$ SMW. B. vishnu species was recorded only a low population in $35^{\text {th }}$, $38^{\text {th }}, 39^{\text {th }}$ and $47^{\text {th }}$ SMW. Likewise, Wen (1985) also recorded two peaks of $Z$. cucurbitae during August- October and MayJune months in Southern Taiwan. Total number of fruit flies was maximum on $35^{\text {th }}$ (14.20 fruit flies/trap) and minimum on $48^{\text {th }}$ SMW (3.90 fruit flies/trap) in cue lure baited traps. Total number of fruit flies trapped was higher in $43^{\text {rd }}$ SMW then population decreased upto $39^{\text {th }}$ SMW. The number was again increased (11.0 fruit flies/trap) and attain a second peak at $44^{\text {th }}$ and $45^{\text {th }}$ SMW.

In methyl eugenol traps, the maximum trapping were noticed on $35^{\text {th }}$ SMW $(25.80$ fruit flies/trap) followed by $37^{\text {th }}$ SMW (13.30 fruit flies/trap) and minimum number of fruit flies was recorded on $44^{\text {th }}$ SMW (3.90 fruit flies/trap). B. dorsalis trapping was more in $35^{\text {th }}$ SMW (22.3 fruit flies/trap) and low in $44^{\text {th }}$ SMW (3.6 fruit flies/trap). The population was maximum on August month and starts declining till November months. Uddin et al., (2016) also documented peak activity of $B$. dorsalis population was recorded only on May-August months during the fruit ripening stages in mango ecosystem. B. zonata was recorded as maximum on $35^{\text {th }}$ SMW (2.3 fruit flies/trap) followed by $37^{\text {th }}$ 
and $42^{\text {nd }}$ SMW (1.3 fruit flies/trap). $B$. correcta species was more in $35^{\text {th }}$ SMW $(1.2$ fruit flies/trap). The abundance of Bactrocera spp. in the month of August observed in this investigation is well supported by the findings of Vignesh et al., 2020, that the peak incidence of fruit flies i.e., 56.50 numbers/trap during the month of August' 17 in mango orchards (Fig. 1).

\section{Fruit fly incidence during rabi 2020}

During rabi season, Z. cucurbitae trap catches were more on $10^{\text {th }}$ SMW (10.6 fruit flies/trap) followed by $9^{\text {th }}$ SMW (9.3 fruit flies/trap) and minimum catches on $3^{\text {rd }}$ SMW (3.3 fruit flies/trap). Z. gavisus species was more in $3^{\text {rd }}$, $6^{\text {th }}$ and $8^{\text {th }}$ SMW (1.0 fruit flies/trap). In case of another species $B$. Vishnu, it was more in $6^{\text {th }}$ and $9^{\text {th }}$ SMW (1.3 fruit flies/trap) (Table 2). Total number of fruit flies was maximum in $10^{\text {th }}$ SMW (12.00 fruit flies/trap) followed by $9^{\text {th }}$ SMW (11.30 fruit flies/trap) and low population was recorded on $5^{\text {th }}$ SMW (4.20 fruit flies/trap) in cue lure traps. Singh and Naik (2006) showed similar result as melon fruit fly population was low during January and increases gradually and attains peak in March, then slowly declines in bitter gourd during 2006.

But in methyl eugenol traps, the maximum population recorded in $10^{\text {th }}$ SMW (12.30 fruit flies/trap) followed by $8^{\text {th }}(11.9$ fruit flies/trap) and $9^{\text {th }}$ SMW (11.6 fruit flies/trap), minimum population recorded on $5^{\text {th }}$ SMW (7.20 fruit flies/trap). B. dorsalis was more on $9^{\text {th }}$ SMW (10.3 fruit flies/trap) and minimum on $3^{\text {rd }}$ SMW (5.3 fruit flies/trap). The population was increased gradually from $5^{\text {th }}$ SMW to $9^{\text {th }}$ SMW in B. dorsalis. Nagaraj et al., (2014) also found the mango fruit fly population was maximum (1.2 fruit flies/trap) during last week of February $\left(9^{\text {th }}\right.$ SMW $)$ then gradually declined till last week of March. $B$. zonata was noticed more in $3^{\text {rd }}$ SMW (1.6 fruit flies/trap). B. correcta was high in $8^{\text {th }}$ SMW (1.3 fruit flies/trap). The peak activity of fruit fly registered during March- June was coincides with the fruiting period of the crop (Sushil Kumar et al., 1997; Sarada et al., 2001) (Fig. 2).

\section{Role of abiotic factors on trapping of fruit flies during kharif and rabi season}

The impact of abiotic factors viz., temperature, relative humidity, rainfall and wind speed on the fruit fly incidence were related by correlation analysis and correlation co-efficient was derived. In kharif season, maximum temperature $(r=0.334)$, minimum temperature $(\mathrm{r}=0.558)$, maximum wind speed $(\mathrm{r}=0.183)$, minimum wind speed $(\mathrm{r}=0.198)$ were positively correlated with trap catches. Rainfall ( $\mathrm{r}=-0.346)$ and relative humidity ( $\mathrm{r}=$ -0.443 ) showed negatively correlated with cue lure trap catches (Table 3). All the weather parameters like maximum temperature, minimum temperature, relative humidity, rainfall, maximum wind speed and minimum wind speed are non significant to fruit fly catches. The present finding is in tune with Dubale et al., (2018) on ridge gourd in Konkan region during kharif season of 2017. But in methyl eugenol traps, maximum temperature $(\mathrm{r}=0.693)$, minimum temperature $(\mathrm{r}=0.835)$, maximum wind speed $(\mathrm{r}=0.550)$, minimum wind speed ( $\mathrm{r}=0.684)$ have significantly positive correlated, but relative humidity $(r=-0.744)$ and rainfall $(r=-0.419)$ have negative correlation with fruit fly catches.

In rabi season, the weather parameters maximum temperature $(\mathrm{r}=0.849)$, minimum temperature $(\mathrm{r}=0.924)$ and maximum wind speed $(\mathrm{r}=0.448)$ were positively correlated, relative humidity $(\mathrm{r}=-0.850)$, minimum wind speed $(r=-0.064)$ and rainfall $(r=-0.301)$ was negatively correlated to trap catches in cue lure traps (Table 4). 
Table.1 Species diversity and abundance of fruit fly in trap catches during Kharif 2019

\begin{tabular}{|c|c|c|c|c|c|c|c|c|c|}
\hline \multirow{2}{*}{$\begin{array}{c}2019 \\
\text { SMW* }\end{array}$} & \multirow[t]{2}{*}{ Date } & \multicolumn{3}{|c|}{ Cue lure } & \multirow[b]{2}{*}{ Total } & \multicolumn{3}{|c|}{ Methyl eugenol } & \multirow[b]{2}{*}{ Total } \\
\hline & & Z. cucurbitae & Z. gavisus & B. vishnu & & B. dorsalis & B. zonata & B. correcta & \\
\hline 35 & 27Aug-02 Sep & 8.3 & 5.3 & 0.6 & 14.2 & 22.3 & 2.3 & 1.2 & 25.8 \\
\hline 36 & 03 Sep-09 Sep & 7.0 & 2.0 & - & 9.0 & 6.6 & 0.6 & 0.3 & 7.5 \\
\hline 37 & 10 Sep-16 Sep & 6.3 & 1.3 & - & 7.6 & 12.0 & 1.3 & - & 13.3 \\
\hline 38 & 17 Sep-23 Sep & 6.3 & 1.9 & 0.3 & 8.5 & 5.6 & - & 0.3 & 5.9 \\
\hline 39 & 24 Sep-30 Sep & 5.6 & 2.6 & 0.3 & 8.5 & 7.0 & 0.6 & - & 7.6 \\
\hline 40 & 01 Oct-07 Oct & 7.0 & 2.3 & - & 9.3 & 6.3 & 0.3 & 0.3 & 6.9 \\
\hline 41 & 08 Oct-14 Oct & 4.6 & 2.0 & - & 6.6 & 7.3 & 0.6 & - & 7.9 \\
\hline 42 & 15 Oct-21 Oct & 7.3 & 0.6 & - & 7.9 & 5.6 & 1.3 & 0.3 & 7.2 \\
\hline 43 & 22 Oct- 28 Oct & 6.3 & 1.3 & - & 7.6 & 6.6 & - & 0.6 & 7.2 \\
\hline 44 & 29 Oct- 04 Nov & 9.6 & 1.6 & - & 11.2 & 3.6 & 0.3 & - & 3.9 \\
\hline 45 & 05 Nov- 11 Nov & 9.7 & 1.3 & - & 11.0 & 5.0 & - & 0.6 & 5.6 \\
\hline 46 & 12 Nov- $18 \mathrm{Nov}$ & 8.3 & 2.0 & - & 10.3 & 5.6 & 0.6 & - & 6.2 \\
\hline 47 & 19 Nov- 25 Nov & 4.0 & 1.6 & 0.3 & 5.90 & 7.0 & - & - & 7.0 \\
\hline 48 & 26 Nov- 02 Dec & 3.6 & 0.3 & - & 3.90 & 5.0 & - & 0.3 & 5.3 \\
\hline
\end{tabular}

* Standard Meteorological Week (SMW)

Table. 2 Species diversity and abundance of fruit fly in trap catches during rabi 2020

\begin{tabular}{|c|c|c|c|c|c|c|c|c|c|}
\hline \multirow{2}{*}{$\begin{array}{c}2020 \\
\text { SMW }\end{array}$} & \multirow[b]{2}{*}{ Date } & \multicolumn{3}{|c|}{ Cue lure } & \multirow[b]{2}{*}{ Total } & \multicolumn{3}{|c|}{ Methyl eugenol } & \multirow[b]{2}{*}{ Total } \\
\hline & & Z. cucurbitae & Z. gavisus & B. vishnu & & B. dorsalis & B. zonata & B. correcta & \\
\hline 3 & 15Jan-21 Jan & 3.3 & 1.0 & - & 4.3 & 5.3 & 1.6 & 0.6 & 7.6 \\
\hline 4 & 22 Jan- 28 Jan & 4.6 & 0.6 & 1.0 & 6.3 & 6.6 & 0.6 & 0.3 & 7.5 \\
\hline 5 & 29 Jan-04 Feb & 3.6 & - & 0.6 & 4.2 & 5.6 & 1.0 & 0.6 & 7.2 \\
\hline 6 & 05Feb- 11 Feb & 5.6 & 1.0 & 1.3 & 8.0 & 7.3 & 0.6 & 0.3 & 8.2 \\
\hline 7 & 12Feb- 18 Feb & 5.0 & 0.6 & 1.0 & 6.6 & 8.3 & 0.6 & 0.6 & 9.5 \\
\hline 8 & 19Feb- 25 Feb & 7.0 & 1.0 & 0.3 & 8.3 & 9.6 & 1.0 & 1.3 & 11.9 \\
\hline 9 & 26 Feb- $04 \mathrm{Ma}$ & 9.3 & 0.6 & 1.3 & 11.3 & 10.3 & 1.3 & - & 11.6 \\
\hline 10 & 05Mar-11Mar & 10.6 & 0.6 & 0.6 & 12.0 & 10.0 & 1.3 & 1.0 & 12.3 \\
\hline
\end{tabular}

* Standard Meteorological Week (SMW) 
Table.3 Correlation between weather parameters and fruit fly trap catches during kharif 2019

\begin{tabular}{|c|c|c|c|c|c|c|c|c|}
\hline \multirow{2}{*}{$\begin{array}{c}2019 \\
\text { SMW }\end{array}$} & \multirow{2}{*}{$\begin{array}{c}\text { CL } \\
\text { catches } \\
\text { (No. of } \\
\text { insects/ } \\
\text { trap) }\end{array}$} & \multirow{2}{*}{$\begin{array}{l}\text { ME trap } \\
\text { catches } \\
\text { (No. of } \\
\text { insects/ } \\
\text { trap) }\end{array}$} & \multicolumn{2}{|c|}{ Temperature $\left({ }^{\circ} \mathrm{C}\right)$} & \multirow{2}{*}{$\begin{array}{c}\text { Relative } \\
\text { Humidit } \\
\text { y }(\%)\end{array}$} & \multirow{2}{*}{$\begin{array}{c}\text { Rain } \\
\text { fall } \\
(\mathbf{m m})\end{array}$} & \multicolumn{2}{|c|}{ Wind speed } \\
\hline & & & Max & Min & & & Max & Min \\
\hline 35 & 14.2 & 25.8 & 35.91 & 25.02 & 56.98 & 0.28 & 5.31 & 1.95 \\
\hline 36 & 9.0 & 7.5 & 34.73 & 23.48 & 65.13 & 0.75 & 5.18 & 1.29 \\
\hline 37 & 7.6 & 13.3 & 34.13 & 23.75 & 66.32 & 6.27 & 3.02 & 0.74 \\
\hline 38 & 8.5 & 5.9 & 33.58 & 23.45 & 70.09 & 5.74 & 2.79 & 1.07 \\
\hline 39 & 8.5 & 7.6 & 30.57 & 23.44 & 79.27 & 7.97 & 2.85 & 0.68 \\
\hline 40 & 9.3 & 6.9 & 31.17 & 23.07 & 77.71 & 4.93 & 2.23 & 0.44 \\
\hline 41 & 6.6 & 7.9 & 31.17 & 23.38 & 78.57 & 4.01 & 1.96 & 0.48 \\
\hline 42 & 7.9 & 7.2 & 29.07 & 23.28 & 86.37 & 13.17 & 2.45 & 0.38 \\
\hline 43 & 7.6 & 7.2 & 28.39 & 22.63 & 87.34 & 10.31 & 2.20 & 0.54 \\
\hline 44 & 11.2 & 3.9 & 27.58 & 22.70 & 87.57 & 10.88 & 2.91 & 0.36 \\
\hline 45 & 11.0 & 5.6 & 29.49 & 22.83 & 84.88 & 3.32 & 1.58 & 0.22 \\
\hline 46 & 10.3 & 6.2 & 29.53 & 22.39 & 86.98 & 2.64 & 2.94 & 0.79 \\
\hline 47 & 5.9 & 7.0 & 29.21 & 22.31 & 87.60 & 2.40 & 3.59 & 0.90 \\
\hline 48 & 3.9 & 5.3 & 28.98 & 22.16 & 88.53 & 9.18 & 3.95 & 1.18 \\
\hline \multirow{2}{*}{\multicolumn{2}{|c|}{ Correlation }} & CL & 0.334 & 0.558 & -0.443 & -0.346 & 0.183 & 0.198 \\
\hline & & ME & 0.693 & 0.835 & -0.744 & -0.419 & 0.550 & 0.684 \\
\hline
\end{tabular}

* Standard Meteorological Week (SMW)

Table.4 Correlation between weather parameters and fruit fly trap catches during rabi 2020

\begin{tabular}{|c|c|c|c|c|c|c|c|c|}
\hline \multirow{2}{*}{$\begin{array}{c}2020 \\
\text { SMW }\end{array}$} & \multirow{2}{*}{$\begin{array}{c}\text { CL } \\
\text { catch } \\
\text { (No. of } \\
\text { insects/ } \\
\text { trap) }\end{array}$} & \multirow{2}{*}{$\begin{array}{c}\text { ME } \\
\text { catch } \\
\text { (No. of } \\
\text { insects/ } \\
\text { trap) }\end{array}$} & \multicolumn{2}{|c|}{ Temperature $\left({ }^{\circ} \mathbf{C}\right)$} & \multirow[b]{2}{*}{$\begin{array}{c}\text { Relative } \\
\text { Humidit } \\
\text { y (\%) }\end{array}$} & \multirow{2}{*}{$\begin{array}{c}\text { Rain } \\
\text { fall } \\
(\mathbf{m m})\end{array}$} & \multicolumn{2}{|c|}{ Wind speed } \\
\hline & & & Max & Min & & & Max & Min \\
\hline 3 & 4.3 & 7.6 & 31.04 & 19.11 & 74.67 & 0.43 & 3.50 & 0.88 \\
\hline 4 & 6.3 & 7.5 & 32.11 & 18.80 & 68.73 & 0.001 & 3.49 & 0.92 \\
\hline 5 & 4.2 & 7.2 & 33.17 & 19.59 & 65.62 & 0.002 & 3.20 & 0.48 \\
\hline 6 & 8.0 & 8.2 & 33.57 & 20.64 & 62.13 & 0.025 & 3.79 & 0.67 \\
\hline 7 & 6.6 & 9.5 & 34.85 & 19.50 & 57.69 & 0.014 & 3.53 & 0.91 \\
\hline 8 & 8.3 & 11.9 & 34.38 & 20.46 & 61.35 & 0.178 & 4.29 & 1.16 \\
\hline 9 & 11.3 & 11.6 & 35.29 & 22.73 & 55.49 & 0.065 & 3.23 & 0.59 \\
\hline 10 & 12.0 & 12.3 & 37.83 & 23.94 & 51.96 & 0.042 & 4.20 & 0.74 \\
\hline \multirow{2}{*}{\multicolumn{2}{|c|}{ Correlation }} & $\mathbf{C L}$ & 0.849 & 0.924 & -0.850 & -0.301 & 0.448 & -0.064 \\
\hline & & ME & 0.832 & 0.803 & -0.801 & -0.070 & 0.591 & 0.233 \\
\hline
\end{tabular}

* Standard Meteorological Week (SMW) 
Fig.1 Weather parameter relationship with fruit fly catches during kharif 2019

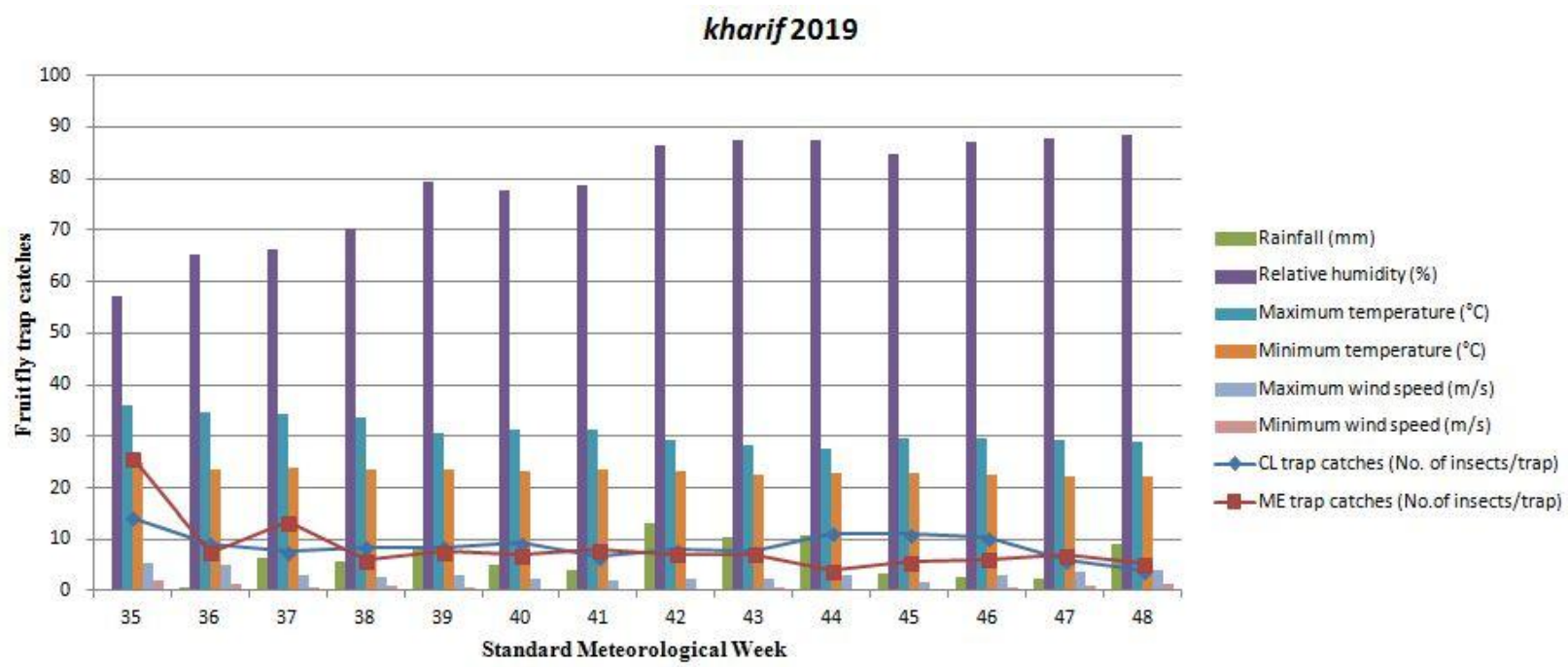

Fig.2 Weather parameter relationship with fruit fly catches during rabi 2020

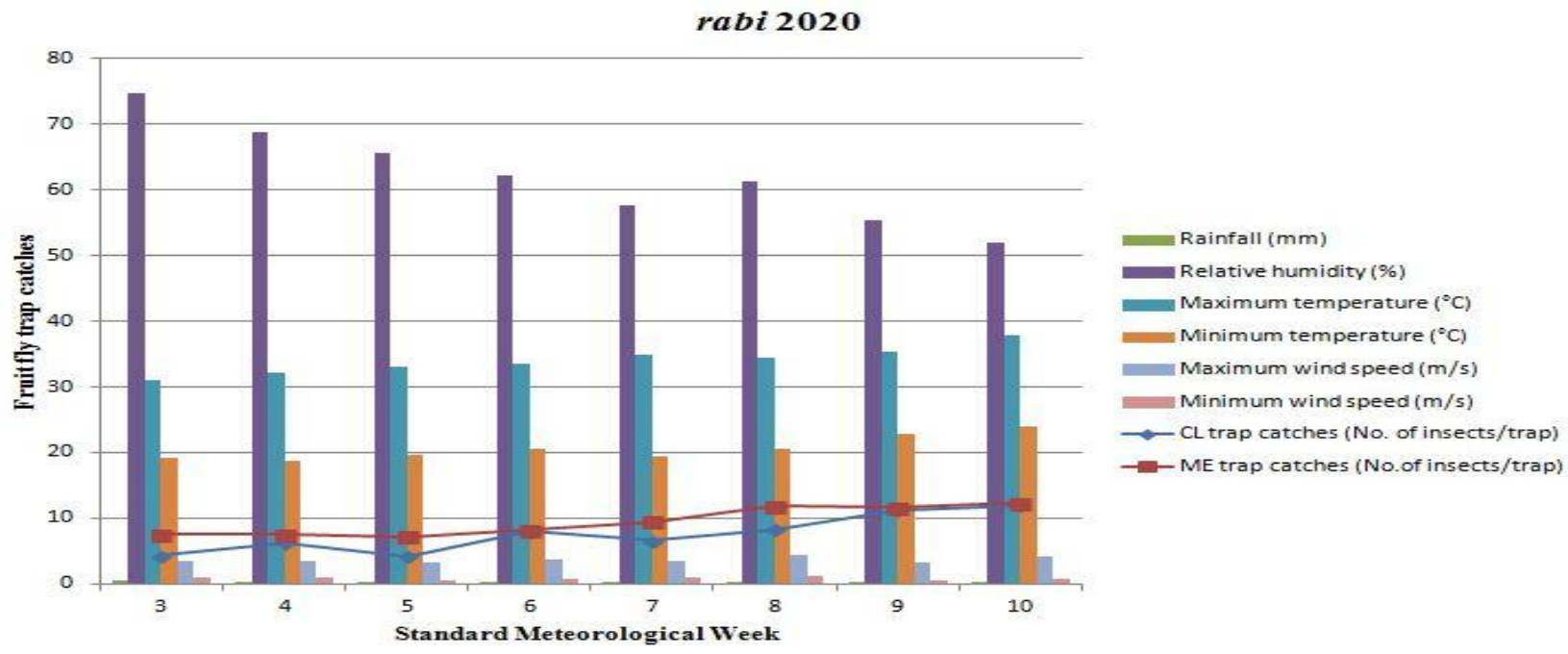

The result was similar with Ghule et al., (2014) fruit fly incidence had positive correlated with maximum temperature $(\mathrm{r}=$ $+0.870)$, minimum temperature $(r=+0.730)$ but had negatively correlated with relative humidity $(\mathrm{r}=-0.738)$ in cucumber. Abhilash et al., (2017) also endowed peak activity of melon fruit fly was recorded on $9^{\text {th }}$ week during fruiting stage in Bommankatte and Basavanagangur villages of the Shivamogga district during 2016-17 in ridge gourd cropping system. The fruit fly catches shown significant positive correlation with maximum and minimum temperature, whereas, relative humidity and rainfall showed the negative correlation with melon fruit fly incidence in the two locations. Maximum temperature $(\mathrm{r}=$ $0.832)$, minimum temperature $(\mathrm{r}=0.803)$, maximum wind speed $(r=0.591)$ and minimum wind speed $(r=0.233)$ were positive correlation but relative humidity $(\mathrm{r}=-0.801)$, rainfall $(r=-0.070)$ were negatively correlated with trap catches in methyl eugenol traps. The positively correlation of temperature and 
negative impact of rainfall and relative humidity over the occurrence of fruit flies in snake gourd ecosystem is also strengthened by the finding of Vignesh et al., 2020, concluded that the influence of external weather parameters on the population of fruit flies shows that rainfall and humidity declines the fruit fly population, whereas the temperature tends to increase the population of fruit flies.

In conclusion, fruit fly incidence and fruit damage is mainly depends on the abiotic factor and species diversity in the cropping area. In Snake gourd ecosystem, the species like Z. cucurbitae, Z. gavisus and B. vishnu species recorded in cue lure traps and $B$. dorsalis, B. zonata and B. correcta species trapped in methyl eugenol baited traps. The results of the present findings indicated that $Z$. cucurbitae population was dominated during November month $\left(45^{\text {th }}\right.$ SMW) and last week of August (35 ${ }^{\text {th }}$ SMW) in kharif and first week of March $\left(10^{\text {th }} \mathrm{SMW}\right)$ in rabi season. B. dorsalis species was maximum during last week of August ( $35^{\text {th }}$ SMW) in kharif and first week of March $\left(10^{\text {th }}\right.$ SMW) in rabi season. The weather parameters, relative humidity and rainfall had negative correlation with fruit fly catches and other parameters showed positive correlation in both cue lure and methyl eugenol traps. Through this finding, farmers can be advised and forewarn to initiate control measures in the early fruiting stage for effective management of fruit fly. The farmers can also be advised for installation of para pheromone traps without any synthetic insecticide use towards a safer environment and eco-friendly management approach.

\section{Acknowledgement}

The authors are thankful to the farmer Mr. S. Manikandan, Kumaravadi village for his generous permission and help to conduct the field experiment in his field. The authors also thank the Professor and Head, Department of Plant Protection and the Dean, Anbil Dharmalingam Agricultural College and Research Institute, TNAU, Tiruchirappalli, for granting permission to take-up the field trial outside the campus and providing laboratory facilities for taxonomic identification of fruit fly species. The support rendered through Student Project Scheme 2019-20 by Tamil Nadu Tamil Nadu State Council for Science and Technology (TNSCST) is duly acknowledged.

\section{References}

Anonymous. 2019. Horticultural database 2018$19, \quad 3^{\text {rd }}$ advance estimate. Area and production published by Ministry of Agriculture.

Abhilash, J., Naveen, NE., Patil, SU., Sharanabasappa, and Mohankumar. KS. 2017. Monitoring of melon fruit fly (Bactrocera cucurbitae) Col. (Diptera: Tephritidae) in relation to weather parameters. Journal of Entomology and Zoological studies, 5(5): 1930-1935.

David, K.J., and Ramani, S., 2011. An illustrated key to fruit flies (Diptera: Tephritidae) from Peninsular India and the Andaman and Nicobar islands. Zootaxa, 3021(1): 1-31.

Deepa Devi, N. 2017. Medicinal values of Trichosanthes cucumerina L. (Snake Gourd) - A Review. British Journal of pharmaceutical research, 16(5):1-10.

Dhillon, M.K., Ram Singh, Naresh, J.S., and Sharma H.C. 2005. The melon fruit fly, Bactrocera cucurbitae: A review of its biology and management. Journal of Insect Science, 1536-2442.

Dubale, MM., Jalgaonkar, VN., Naik, KV., Munj, AY., and Golvankar, GM. 2018. Studies on incidence of fruit flies in relation to weather parameters on ridge gourd in Konkan region. Journal of Entomology and Zoology Studies, 6(5): 2012-2014.

Ghule, TM., Bhajanlal Uikey, Pranab Barma and Jha. 2014. Incidence studies on some important pests of cucumber (Cucumis sativus L.). An International Journal of 
Environmental Sciences. 177-180.

Hardy, D. E. 1979. Review of economic fruit flies of the South Pacific region. Pacific Insects, 20: 429-432.

Mathew, S., Dhande, SD., Salve, RN., and Ekamalli, PC. 2019. Economics of Snake gourd production in Konkan region. Journal of Pharmacognosy and Phytochemistry, 8(1): 456-459.

Nagaraj, K.S., Jaganath, S., Shafeeq Bawoor, Srikanth, L.G., and Mahamadtoufeeq Husainnaik. 2014. Incidence of Fruit Fly (Bactrocera spp.) in different Mango Orchards and Varieties. Trends in Biosciences, 7(11): 1072-1074.

Narayanan, ES. 1953. Seasonal pests of crops. Indian Farming, 3(4): 29-31.

NASA POWER, 2020. http:// power. Larc. Nasa. Gov/. 27 March, 2020.

Nasiruddin, M., Alam, S.N., Khorsheduzzaman, A.K.M., Rahman, A.K.M.Z., Karim, A.N.M.R., Jasmine, H.S., and Rajotte, E.G. 2004. Integrated management of cucurbit fruit fly, Bactrocera cucurbitae Coquillett in Bangladesh. IPM CRSP Bangladesh Site Tech, Bull. No.1. P. 16.

Neupane, FP. 2000. Integrated management of vegetable insects. CEAPRED, Bakhundol, Lalitpur, Nepal. Pp. 172.

Raghuvanshi, AK., Satpathy, S., and Mishra, DS. 2012. Role of abiotic factors on seasonal abundance and infestation of fruit fly, Bactrocera cucurbitae (Coq.) on Bitter gourd. Journal of Plant protection research. Vol. 52. 264-267.

Sarada, G., Maheshwari, T. U., and Purushotham, K. 2001. Seasonal incidence and population fluctuation of fruit flies in mango and guava. Indian Journal of Entomology, 63: 272-276.

Singh, H. S., and Naik, G. 2006. Seasonal dynamics and management of pumpkin caterpillar, Diphania indica Saunders and fruit fly, Bactrocera cucurbitae Coq. in bitter gourd. Vegetation Science, 33 (2): 203-205.

Suresh Babu, KS., and Viraktamath, S. 2003. Species diversity and population dynamics of fruit-flies (Diptera: Tephritidae) on mango in Northern Karnataka. Pest Management and Economic Zoology, 11(2):103-110.

Sushil Kumar, Patel, C. B., and Bhatt, R. I. 1997. Studies on seasonal cyclicity of Bactrocera correcta Bezzi in mango and sapota orchards using methyl eugenol trap. Gujarat Agricultural University Research Journal, 22: 68-74.

Uddin, M.S., Reza, M.H., Hossain, M.M., Hossain, M.A. and Islam, M.Z. 2016. Population fluctuation of male oriental fruit fly, Bactrocera dorsalis (Hendel) in a mango orchard of Chapainawabganj. International Journal of Experimental Agriculture, 6(1): 1-3.

Vignesh,S., Chandrasekaran, M., Ambethgar,V., Jeeva,S. 2020. Species Diversity and Population Dynamics of Fruit flies in guava orchards. Journal of Entomology and Zoological Studies, 8 (3): 615-619.

Vignesh, S., Chandrasekaran, M., Jeeva,S. and Sithanantham, S. 2020. Impact of climatic factors on seasonal occurrence and species diversity of fruit fly, Bactrocera spp. in mango orchards. Journal of Entomology and Zoological Studies, 8 (3): 1012-1015.

Wen, H.C. 1985. Field studies on melon fruit fly (Dacus cucurbitae) and attractant experiment in southern Taiwan. Journal of Agricultural Sciences in China, 32: 228235 .

\section{How to cite this article:}

Sowmiya, L., M. Chandrasekaran, R.P. Soundararajan and Ramesh, D. 2020. Influence of Weather Factors on the Occurrence, Population Fluctuation and Species Diversity of Fruit Flies in Snake Gourd Ecosystem. Int.J.Curr.Microbiol.App.Sci. 9(09): 165-173. doi: https://doi.org/10.20546/ijcmas.2020.909.020 